\title{
Creation, Transfer and Utilization of Knowledge: A Case Story of the "Knowledge Gardening" Process for Survival
}

\author{
Karl Gustaf Svanström \\ Department of Industrial Economics and Management, Royal Institute of Technology, Sweden
}

Copyright $(2016$ by authors, all rights reserved. Authors agree that this article remains permanently open access under the terms of the Creative Commons Attribution License 4.0 international License.

\begin{abstract}
A company does not only consist of machines, plants and technology as resources. It also includes people with knowledge. This human capital added with ambitions and creativity to build strategies make the company survive in the international context. Even though internationalization has been much studied the main attention has lied in the focus of crossing a national border, which also is the traditional definition of internationalization. But the internationalization of businesses also includes how to make sense, building strategies to survive. The internationalization of businesses must therefore be looked upon as a longitudinal "never-ending" process. This paper presents a case study of the Swedish company CA Clase. It shows how creation, transfer and utilization of knowledge were necessary to over-win barriers and build strategies to make sense and survive in the international context. The knowledge process is looked upon as a strategic communication tool. The knowledge had been accumulated and embedded during many years. Through meetings, interviews, reading of protocols and written notes the knowledge could be reconstructed. The work-perspective was hermeneutical and could at the same time be looked upon as a resource based view. That work was here called knowledge gardening, which was a way to collect and sort out implicit and explicit internal as well as external knowledge.
\end{abstract}

Keywords Knowledge Gardening Process, Survival, Reborn, Communication, Creativity, Barriers, Knowledge Management, Internationalization, Value Creation, Strategy, Brand, Payoff

\section{Introduction}

Several years ago I was asked to make a study to see how 50 Swedish subsidiaries have managed to succeed in the
Schleswig-Holstein region. The study showed that not a single company remained as a Swedish subsidiary. The patterns were often the same with gaps in creation, transfer and utilization of knowledge and a lack of a sense-making process. This started up my curiosity and interest to get an answer to how and what was needed to survive and become sustainable in an international context. What role could knowledge and communication play for sense-making in the internationalization process?

Regardless of a large and also growing amount of studies looking at various aspects of firms internationalization, several answers remain in our understanding of the internationalization process as a whole. In this paper I examine two deficiencies. First, internationalization is a phenomenon researched intensively over the last few decades from a variety of viewpoints, including: organization theory, marketing, strategic management, international management, and small business management. Issues such as international decision-making and management, the development of international activities, and factors favoring or disfavoring internationalization have been studied for both large as well as small businesses (50). Internationalization is a synonym for the geographical expansion of economic activities over a national country's border. The economic internationalization process accelerated in the post-second-world-war era and appeared unrivalled until the early 1970s, when a new phenomenon of globalization started to emerge (26). But the internationalization of businesses also includes how to make sense, build strategies and survive. That has been less studied. Second, knowledge has become an increasingly popular and widely used concept. The assumption behind the concept is that the tangible and financial resources that have dominated the management agenda for years have had to leave room for knowledge as powerful intangible resource that organizations need to focus on to survive. Knowledge has become an increasingly popular and widely used concept. The assumption behind the concept is that the 
tangible and financial resources that have dominated the management agenda for years have to leave room for knowledge as powerful intangible resource that organizations need to focus on to survive. Knowledge has become a main source of value in organizations. Indeed organizations need to develop, share, codify, capitalize on and manage their knowledge to ensure their future profits and competitiveness (e.g. 20, 5, 51, 52). When entering into the knowledge there is an increasing need for tools supporting the development, measurement and sharing of knowledge. For instance, databases have been set up to collect, codify and store knowledge. Researchers have indicated that few organizations working with these tools succeed in this work mostly because they do not reach the development of shared knowledge $(45,47)$. An alternative view of knowledge is taking a processual view. Within the processual epistemology it is not resources or end products that are in focus, instead it is the processes whereby these resources become constructed. Within this line of theory some would even argue that knowledge does not develop into something, but is instead per se seen as a process (16). Within situated practiced theories this epistemological approach has been widely developed. The focus in these theories is on bridging the otherwise often assumed gap between thinking and practice. Some interesting work has been done where focus is on knowledge as a process (37, 16). This paper will connect these two issues by exploration of knowledge creation and usage in the context to the internationalizing process to investigate the hermeneutic making of sense and strategy. Sense making can be seen as the ability or attempt to make sense of an ambiguous situation. More exactly, sense-making is the process of creating situational awareness and understanding in situations of high complexity or uncertainty in order to make decisions. It is "a motivated, continuous effort to understand connections (which can be among people, places, and events) in order to anticipate their trajectories and act effectively" (36). The paper is based on a case study of CA Clase in Gothenburg who lost the market and was forced to reconstruct the knowledge base to fit other market-segments which naturally affected the whole organizational structure. Their knowledge depends on "their absorptive capacity, which is largely a function of the firm's level of prior related knowledge" (15).

\section{The Internationalization of Firms}

After the World War II the global population was approx. 2500 millions of people and today (2010) our global population is about 6500 millions of people. One effect of that is an increase in business events and also a change from local to national to international and to global business. These changes in perspectives have resulted in a requirement to understand and therefore internationalization researches have increased intensively over the last decades. The rapid change especially from internationalization to globalization has put earlier internationalization research and theories under pressure. The traditional definition of internationalization is a company crossing a border but today's technology enables global presence in a way that was impossible earlier. This new manner in the changing internationalization and global businesses has to be researched and understood also in the perspective of how to survive and to be sustainable in contexts in change. But we know less about how to survive and become sustainable. This research focus seems to have been forgotten in the shadow of the focus of the crossing-the-border research.

Referring to (50) "earlier research has focused on internationalization mainly from the point of view of the firm's international activities or operations by applying product, operation, and market analyses (e.g. 40)". Researchers had a tendency to define internationalization in different ways even though their focus is on process and the firm's operations. Luostarinen (1979) and Johanson and Wiedersheim-Paul (1975) defined the process as evolutionary. Johanson and Vahlne (1990) defined the process as "a cumulative process in which relationships are continually established, developed, maintained and dissolved in order to achieve the firm's objectives" (50). Johanson and Mattson (1993) defined it as "the process of adapting firms' operations (strategy, structure, resources etc.) to international environments and they together with other researchers brought in the network analyses approach (e.g. 31). while Welch and Luostarinen (1993) saw it as " the outward movement of a firm's international operations" and Calof and Beamish (1995) saw "internationalization as the process of increasing involvement in international operations" which at a certain point could become inverted and lead to de-internationalization (6).

This network analyses approach was also a focus for Lehtinen and Penttinen (1999) together with a relationship approach and defined internationalization as "developing a networks of business relationships in other countries through extension, penetration and integration" (50). The same year Lehtinen and Penttinen discussed internationalization in terms of " primarily inward, outward and cooperative operations".

(Gjellerup, 2000) saw how globalization as new phenomenon started to emerge and Ahokangas (1998) had a focus on internationalization as resources and process. Ahokangas defined internationalization as; " the process of mobilizing, accumulating and developing resource stock for international activities". He looked upon internationalization from a resource-based perspective.

Ruzzier, Hisrich, Antoncic, (2006) describes Ahokangas (1998) resource-based perspective as to; "mobilize unique and interdependent resource stocks that enable and contribute to the firms internationalization activities within its natural context. This definition thus implies that internationalization is the process of mobilizing, accumulating, and developing resource stocks for international activities, 
regardless of the actual content of the international activities themselves".

As in the case of CA Clase the involvement in international business started when they bought products from abroad and cooperated with foreign companies and sold their products to shipping companies, engineering industry as a trader in Sweden and to foreign markets. That was the tradition ever since the start 1911. The operations was both "inward" and "outward" and "cooperative", which shows that CA Clase has a "holistic nature of internationalization" (35). "Knowledge of the outward internationalization process and related operations is more complex than that for inward internationalization" according to Ruzzier, Hisrich and Antoncic, 2006. In Scandinavic countries traditionally internationalization has been defined in terms of; "the process of increasing involvement in international operations" (59) and "this process has often been understood as gradual and sequential, consisting of several stages" (50). Relatively few studies exist on inward behavior (see, e.g., 25). Even fewer studies investigate companies that have both an inward and an outward behavior in their internationalization process, as was the perspective for CA Clase.

The research stream has been focused first on the process and the firms operation via networks and relationships to relationships, firms operations, processes and international environment to a resource-based perspective. "The resource-based view of strategic management focuses on sustainable and unique costly-to-copy attributes of the firm as the sources of economic rents, i.e. as the fundamental drivers of the performance and sustainable competitive advantage needed for internationalization", (50). Through this model companies could develop different internationalization strategies but we still only express internationalization as a process and say nothing about how the resources should be used and sustainable in terms of surviving. A key question is how researchers have defined the process. We know the "crossing-a-border" internationalization process starts but do not know it ends in a surviving "never-ending" sustainable situation.

Fundamental factors regarding resources are information, knowledge, organizational learning and sense making and Huber (1991) conceded that organizations can learn through conducting a focused search for new information, triggered by a problem or an opportunity, rather than through experience from own activities. CA Clase who lost the market was forced to reconstruct the knowledge base in their internationalization process to make sense. As mentioned above, traditional internationalization researcher have at first paid less attention how companies survive in a never-ending internationalization process and second how companies retention the initiative to make sense.

\subsection{Sense-making}

To talk about sense-making is to talk about reality as an ongoing accomplishment that takes form when people make retrospective sense of the situations in which they find themselves. There is a strong reflexive quality to the process. People make sense of things by seeing a world on which they have already imposed what they believe (58).

The concept of sense-making contains two main logical moments: the retrospective process of interpretation (sense) and prospective one of enacting a new configuration of environment (making). The sense-making process influences what and how data is to be considered and judged by the subject in order to implement future actions. In this sense, Weick proposes the concept of enactment used to describe the way an agent alters and changes its environment through committed action (56). In ambiguous situations, once an interpretation is formulated, decision makers are able (have the opportunity) to enact an environment favorable to such interpretation. In enactment, people actively construct the environments which they attend to by bracketing, rearranging, and labeling portions of the experience, thereby converting raw data from the environment into equivocal data to be interpreted. In selection, people choose meanings that can be imposed on the equivocal data by overlaying past interpretations as templates to the current experience. Selection produces an enacted environment that provides cause-effect explanations of what is going on. In retention, the organization stores the products of successful sense making (enacted or meaningful interpretations) so that they may be retrieved in the future (13).

Sense making can be seen as the ability or attempt to make sense of an ambiguous situation. More exactly, sense making is the process of creating situational awareness and understanding in situations of high complexity or uncertainty in order to make decisions. It is "a motivated, continuous effort to understand connections (which can be among people, places, and events) in order to anticipate their trajectories and act effectively" (36).

Karl Weick has been one of the main advocates of the sense making perspective within organization theory. Weick describes sense making in terms of a number of properties that stress its dynamic, social and retrospective nature. Weick also argues that sense making involves improvisation, identity construction and the construction of plausible narratives as individuals cope with ambiguity in interpretation. Developing a view of organizations as activity systems, Blackler (1995) argues that research into sense making within organizations should recognize that processes of knowing are increasingly mediated by information technologies, contested in the sense that managerial and professional expertise may come into conflict as well as being situated within communities-of-practice.

As mentioned above enactment is connected to sense-making and Weick (1988) describes the term as representing the notion that when people act they bring structures and events into existence and set them into action. Weick uses the term enactment in the context of 
sense-making by managers or employees. "He describes how they can enact limitations upon the system to avoid issues or experiences. It is seen as a form of social construction and enactment is related to organizations and their environment and strategic management" (50).

According to Weick (1979) and Deetz (1982) organizations are in a constant process of organizing. This is a way to obtain continuity and coordination which needs actors and roles to coordinate the activities. "Eisenberg (1986) claimed that processes occur in two ways; they achieve stability through enactment of interaction cycles or through the development of rules" (50). Members in an organization are conscious of their relationships which results in enactment that is related to organizations. They cannot separate themselves as individuals or as members in the organization regarding to how they think about the meaning they affect themselves or other actors and the environment. "The external environment literally bends around the enactments of people, and much of the activity of sense-making involves an effort to separate the externality from the action $(37,50)$. Weicks conclusion is that members in an organization engage not only each other but also their organizations and their environment. A researcher can get helped by investigating enactment and identify structures in organizations as interpersonal, groups and organizations as well as become aware of communication-structures and predict informal networks. Much enactment is routine, scripted as communication plans and random more often than strategic.

Weick's (1995) conceptual model is an organizational-model not an organizational-type or structure that describes a process. Briefly the model describes the organization as a part of an external environment that supplies the organization with information. Because of that the organization has an information-problem. The organization solves that situation in different ways depending of the degree of complexity or ambiguity. The organization develops norms and cycles for problem-solving and in that sense communication and handling of information have an active part. The aim for the organization is to process incoming information in such a way that the complexity or the ambiguity is reduced to a level that the information is understandable. The process is to a greater part communication- and information-handling, and according to Weick it is the task for the organization.

A key notion in the model is information environment, which is the external environment the organization is in. Weick does not describe the external environment as consisting of organizations but of the information as the individuals in the organizations reacts upon, i.e. the information that have relevance for the organization in some way. The external environment is therefore information, and more specifically different information-sources dependent on the data as the organization or the individuals in the organization have. In that perspective one can say that an external environment analysis defines what external environment one exists in.
What kind of information the organization chooses to add in the external environment analysis is defined by the external environment.

The notion of the external environment is central in organizational theory. For a better understanding of the interaction between the external environment and the company strategy one have to ask the question; what is the external environment? The external environment gives meaning to a successful strategy and as the scientists discuss different types of strategies they also discuss different types of external environments. In the article "Strategic Management in an Enacted World" Linda Smircich and Charles Stubbart bring forward the answer is that it could be objective, lived or created. The objective does not allow the individual perception of the external environment, which means that it could be different in different lines of business. The lived external environment you have to discover while the created (enacted environment) comes to us through our experiences according to Smircich and Stubbard. That means that the lived external environment is created back way through logic, sense-making and interaction domains arise Weick, 1995). This acting behavior seen over a time period creates patterns which require a collective thinking. This is governed between individual and collective as company, branch etc.

\subsection{Creativity and Innovation is Born out of Knowledge}

What is creativity and what is innovation? In the CA Clase case this is of certain interest of one obvious reason how to survive; what to do when the main target group disappeared. That barrier required all types of knowledge to be used creatively and innovatively. There are several definitions of those and they are not often distinguished. They are simply seen as part of the process by which knowledge is developed and transformed in the internationalization process. This is an acceptable definition, but again like the difference between information and knowledge it is not very useful for the purpose of discussing the subject area. A more useful approach is to view creativity as the process of generating ideas whilst seeing innovation as the sifting, refining and most critically the implementation of those ideas. Creativity is about divergent thinking. Innovation is about convergent thinking. Put simply, creativity is about the generation of ideas and innovation is about putting them into action. Creativity, to come up with new ideas, is not enough. We need innovation, the taking of new or existing ideas and turning them into action (28). This requires the application of existing knowledge and the development of appropriate new knowledge. Also coming up with new ideas is the food of innovation. Innovation is a far tougher proposition than creativity.

Fillis (2002) writes in his paper "An Andalusian Dog or a Rising Star "about creativity that; "Creativity is a driver of competitive advantage. It is found in firms of all sizes, but 
perhaps has greatest impact within the entrepreneurial smaller firm" (24). Business creativity has existed in a variety of forms for centuries and can be traced to the Italian Renaissance", (23), and Pre-Hellenistic Greece (41). Although creativity is mentioned within entrepreneurship texts, much of this is fairly recent (3) and in some cases, only linked to innovation or not at all (12). No historical precedence is uncovered for the existence of creativity as a business competency and as a phenomenon worthy of further study. Creativity as a research area is a growing area of enquiry $(22,23,24,29)$. Researching the phenomenon can be traced to areas outside the traditional boundaries of business and marketing:

The study of creativity, as no other subject, brings into a single arena the many characters of psychology, biography, literature and art. In trying to understand how man's greatest achievements come about, the initial focus is...upon the creative product...such as great works of art or science...The study of creativity need not limit itself to the eminent, the extraordinary. There are kinships between the small and the great and perhaps even between the creativity of everyday life and that of a great scientist or artist (27).

A particular practice is regarded as creative if it goes beyond the mere repetition of learned formula and procedures. The concept of creativity is linked to notions of genius, imagination and subjectivity. Genius is a union of imagination and understanding says Ramplay (1998).

In the long run no really subtle, deep, and far reaching problems can be solved in any field whatsoever, except by people who are able to respond in an original and creative way to the ever changing and developing nature of the overall fact by which they are confronted (4). There is nothing more difficult to plan, more doubtful of success, more dangerous to manage than the creation of a new order of things. Concerning researching creativity you can look upon it as a psychological trait, as a social factor or as an entrepreneurial marketing factor. You can also look at it at an individual, group or firm level. Interest in entrepreneurship and small business grew in 1980s as internationalization research and smaller firms did. Marketing/entrepreneurship interface paradigm can explain smaller firm behavior as informal, unstructured, chaotic, unplanned and opportunistic. Marketing and entrepreneurship share conceptual and practical ground and that this commonality can be made sense of in the context of a conceptual framework which emphasizes the applied creative problem solving dimension of each field, Thus to the extent that creative behavior is a significant feature of radical marketing success, it might also be said to lie at the heart of much successful entrepreneurial endeavor (29).

To develop creative competencies it could be better to be simple rather than complicated and to have a willingness to accept sometimes basic ideas to gain result in competitive advantage. A cult of change may be needed and it could also be easier to establish it in the smaller firm in a dynamic environment cause its more flexible. Rentschler et al. (1996, 1997, 2000) promote need for balance of entrepreneurial creative and business competencies.

\section{Organizational Knowledge}

For an organization the capability to learn is central in the internationalizing process. Especially for a company that have to reorganize knowledge in real practice like CA Clase. Knowledge as being situated in practice is presented in activity theory and situated learning theory that are largely based Vygorsky's (1962) work. The theories primarily focus on the nature of practical activities, their social origins and the nature of the communities of practice within which individuals interact. The reasons to look into these theories are that they represent knowledge as a process perspective. They also primarily take activities as a unit of analysis and define the actors involved in them thereafter. Rather than following the performance of a predetermined group of actors, different actors who are engaged in various practices are studied. This will explain the dynamics of the activities rather than of the actors themselves. Another reason is referred to that most basic assumptions in the theories are that actors develop and use intellectual and physical tools to construct their reality. Although the tools are not seen as actors in themselves, they are central to the actors construction of and practice in each situation.

There is a difference between knowledge and learning, where knowledge is part of practice and therefore pragmatic but it is also social as distributed between actors. Learning is also an integrated part of practice and by focusing on the situatedness of learning, the theory leaves out other processes related to situation-based knowledge. Learning improves the ability to engage in and develop practice, but not necessarily improvements. This process can be referred to as knowledge-processes. This knowledge-access gives a new knowledge-structure and a new knowledge-process in a continuum. Knowledge through talk means that talk is a part of what has been referred to as practice and a part of the knowledge process. Language on the other hand is the tool that enables knowledge processes to take place; consequently, talk and the use of language have to be examined to fulfill the purpose of the thesis.

When studying and representing knowledge something have also to be said about actors, practice and context and the construction of reality where I refer to Berger and Luckmann and Barbara Czarniawska. When actors talk, they negotiate about the use of language in specific context. Hereby language is continuously being constructed and reconstructed during practice while at the same time language gives structure to practice and consequently to talk. This view of talk as practice and the use of language as a part of the knowledge processes are closely related to narrative knowing. The narrative mode of knowing consists in organizing ones experience. Practice sets out with a goal, 
but as Czarniawska (1997) argued, the most important aspect of it is the formulation and reformulation of that goal. It is the trip toward the goal and thereby the formulations taking place on the way that becomes structured through narration. Practices are assumed to become structured into what Czarniawska $(1997,1998,1999)$ labels a meaningful whole. This meaningful whole consists of constructions of past, present and future situations. A reconstructing of present and future events is dependent upon the actors' experiences or anticipations of experiences.

\subsection{Narrative Approach to Knowledge}

Referring back to the processual perspective of knowledge, narratives are seen as a way of making. As Weick (1995) put it; "narration is a way of making sense of what is going on or of what has taken place already". Czarniawska (2006) takes in her paper; "The uses of Narrative in Organization Research" up the variety of ways of reading narratives. She classifies them into the three steps delineated in the hermeneutic triad: explication, explanation, and exploration. Explication raises the issues of interpretation and over-interpretation; and finds different solutions in pragmatist vs. traditional hermeneutic theory of interpretation. Explanation has a wide range of techniques and approaches to offer, from structuralism through poststructuralism to deconstruction. The narrative approach will give a closer understanding of how the process develops, how barriers are handled and how a sense-making internationalizing process emerges.

A narrative approach can also be seen as organizational learning of knowledge related to specific dynamic market knowledge. In this paper knowledge is looked upon as dynamic, where the key is the interaction between tacit knowledge and explicit knowledge (42). The creation of knowledge takes place through four different modes of knowledge conversion: socialization, externalization, combination and internalization (34). Socialization is the conversion of tacit knowledge to tacit knowledge; combination is the conversion of explicit knowledge to explicit knowledge; externalization is the conversion of tacit to explicit knowledge and internalization is the conversion of explicit to tacit knowledge (42). Nonaka (1994) asserts that organizational learning results from a process in which individual knowledge is transferred, enlarged, and shared upwardly to the organizational (strategic, author) level. This process is characterized as a spiral of knowledge conversion from tacit to explicit. This is the whole idea of the knowledge spiral, also referred to in my conceptual framework. The knowledge spiral is the link between an individual's tacit knowledge and organizational knowledge through the four modes of knowledge conversion $(43,34)$.

\subsection{Barriers to Knowledge Creation}

Information that creates knowledge can be asymmetrical and create barriers that make the internationalization process difficult. In everyday efforts a company don't need much new information or lots of new ideas. They need to think about the information and knowledge that they already have but in new ways. The company could also be in a contextual structure that contains many barriers. One reason to failure to manage is that there are barriers to creativity and innovation, and not until these assymetrics are removed they can use their creativity in full (28).

In this paper asymmetries as barriers are defined according to their origin (internal/external conditions) and nature (tangible/intangible). The typology that categorizes barriers to growth and sustainability as internal or external, and as tangible or intangible, was originally presented by Ylinenpää (1996) and has been used in the studies of barriers to innovation in Europe.

Nonaka and Takeuchi (1998) argue that certain conditions need to be satisfied for organizational knowledge creation to take place: for example, an organizational intention to create knowledge, individuals in an organization being allowed to act autonomously to create new knowledge, and organizations counteracting a certain amount of "fluctuations and creative chaos" (34).

\section{Conceptual Framework}

The main objective of the research in this paper was to investigate the connection between internationalization and the creation and utilization of knowledge to make sense. How such connections develop and how they can be utilized to create competitive advantage through continuous knowledge development for even stronger sense-making will be investigated in the CA Clase case. The study also sought to discover barriers that can hinder the development of creation and utilization of knowledge.

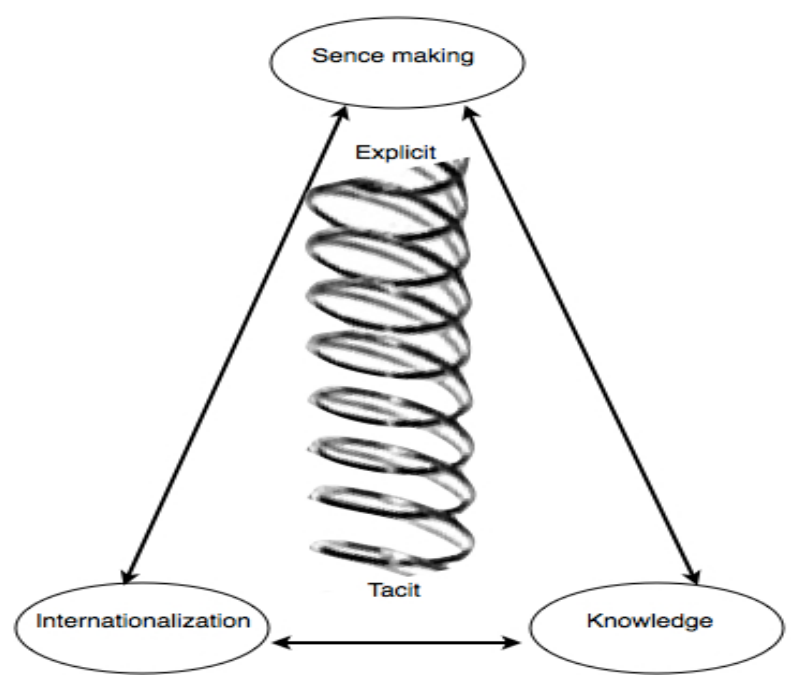

Figure 1. Conceptual framework.

As presented in my conceptual framework (fig. 1) the analysis focuses on three main processes; (1) the 
internationalization process, (2) the creation and utilization of knowledge and (3) the sense making process. Referring to earlier literatures studies I argue that those three main processes are closely interlinked (fig 1.) and in between there are both horizontal and vertical organizational communication processes which drives the organizational hermeneutical knowledge learning process from tacit to explicit as well as from explicit to tacit knowledge in a continuum.

The actual situation for CA Clase put the internationalization efforts under strong pressure and knowledge creation, transfer and utilization was necessary for making sense and survival. A resource based view was necessary in terms of; what can we offer to make sense when our market is gone.

\section{Method}

Most studies regarding internationalization processes have a macro or micro perspective and do not focus on the internal processes. To understand these there is a need for more in-debt case studies and in-process research as part of a more general emphasis on longitudinal research (Korhonen, 1999). Earlier researches have more used cross-sectional methods and static models making it difficult to analyze and understand the complex and the dynamic nature of internationalization (34).

In line with this perspective I undertook the work and investigation of the Swedish company CA Clase to study the role of creation and utilization of knowledge in the internationalization process for making sense and build a survival value-creating strategy. In this study my perspective is hermeneutical. The starting point for my investigation was in the mid-80s when the main target group, the shipyards in Gothenburg disappeared and CA Clase was pushed into a longitudinal survival process. The company, at that time a trader from Bergman \& Beving, was divided into the following divisions; instruments and electronics, super-sealings, consultation and cooperation and environmental control - safety and economy.

The data collected from different sources are used as a parallel tool for comparing data collected from interviews. One of the strengths of case studies is the possible of using multiple data sources, both quantitative and qualitative. I therefore consistently as well as because of good circumstances used multiple sources of evidence (data triangulation) to strengthen the validity of the research $(2$, $44,60)$.

Data collected from the studied period are different scripts as, plans, meeting-protocols, telephone-notes, e-mails, commitments, presentations, sketches, photos, meeting agendas, printed materials under work and company-written plans. All this scripts are collected over a long period of time both before and after the investigation period. Yin (1994) outlines three principles to be followed in the data collection procedure; to use multiple sources of evidence, to create a case study database and to maintain a chain of evidence. For this study there have also been collected data from today's data-bases as; websites, industry associations, annual reports and other publications. The data collected focus on creation and utilization of knowledge, decisions and actors acting. In the research I have undertaken both formal structured and semi-structured in-depth interviews as well as informal follower together with the respondents in daily work during 1985 to 1990. This is completed with formal structured and semi-structured in-depth interviews during 2009. All different interviews have helped to clarify the content of some of the secondary data collected to ensure the validity. The data collected from semi-structured interviews have not only provided answers, but also reasons behind. Reliability refers not only to the findings and results achieved but also reproduced by other researcher. Secondary data used are industry association data, annual reports and other publications. This sources transcribed or edited from primary sources may include errors that the transcribing and editing process made. Therefore I had evaluated the creditability of the sources as well as triangulated the findings with other independent data sources. There may be disadvantages which could affect the outcome of the study, as the data could have been collected for a different purpose. The document can represent those who produced them more than the studied object or there could just be bad quality. When analyzing the case-study data was checked from the interviews continuously against other different sources as a way to crosscheck the reliability and to avoid that essential information not was missing. The main analysis of the case study followed a logic approach, a combination of pattern-matching and time-series analysis (60) as a way to discover the cause-and-effect pattern.

\section{The Case}

\subsection{Company Background}

Company CA Clase has a long tradition in shipping. The founder Carl Albin Clase started up as a businessman in the firm August Leffler \& Son 1909 and in 1911 under his own name CA Clase. Already during 1901 up to 1904 he ran business in London under the name Chas. W. Huss \& Co. $\mathrm{He}$ began with rust-protection and insulation and his son Viking Clase consolidated these activities and developed the company with different mechanical and instrument components to complete systems within navigational safety and sealing technology. His grandson Lars $\mathrm{T}$ Clase developed new insulating methods further.

Through creativity and application CA Clase acted as a link between the manufacturer and customer, a link which not only answers for delivery of goods but through experience and expert-knowledge is able to provide package solutions for complete systems and for highly qualified consultative services. CA Clase market instruments for the 
industry, shipping and armed forces, mechanical seals, products within the energy saving and safety fields, industrial insulation and decontamination. The various divisions which are administratively independent but works in collaboration wherever necessary even though they may appear to have widely varying areas of business and customer categories. There is a logical relationship between them as can be seen from the diagram below.

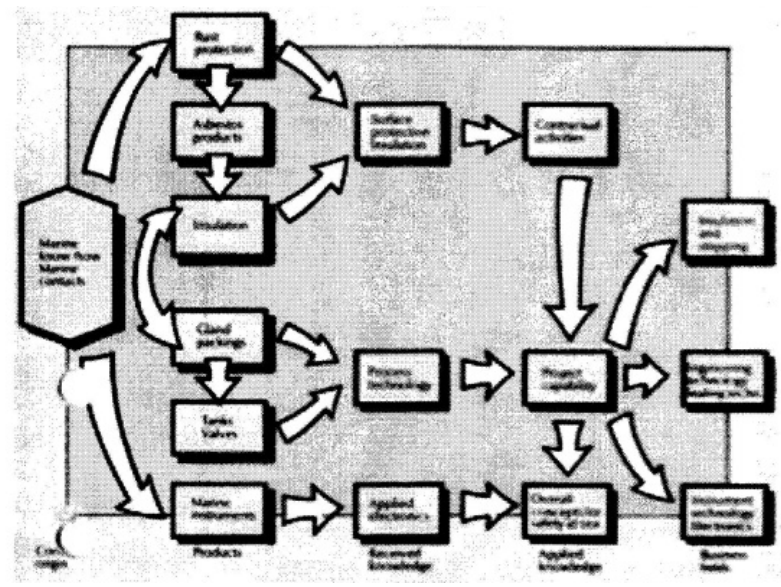

Figure 2. CA Clase Marine know-how

The company origin is "Marine know-how and Marine contacts" where they can offer products in six different areas; rust protection, asbestos, insulation, gland packings, tank valves and marine instruments.

They look upon knowledge as received and applied. The received knowledge is divided into three categories; surface protection and insulation, process technology and applied electronics. The applied knowledge is divided into contractual activities, project capability and overall concepts for safety at sea. The project capability is then divided into three business fields Insulation and stripping, Engineering and sealing technology and Instrument technology and electronics.

\subsection{Knowledge Creation, Transfer and Utilization in the Internationalization Process}

During the mid-80s CA Clases main target group, the shipyards in Gothenburg disappeared. At the same time CA Clase had coordinated all their activities under one roof and 1984 they opened their new premises comprising a floor area of $5000 \mathrm{~m} 2$ (853820 FT2) for offices, workshops and stores. In 1985 everything was ready, giving them an additional space of $3000 \mathrm{~m} 2(32300 \mathrm{ft} 2)$ for offices and workshops. Even if the situation was severe the rhetoric was offensive, hopeful but set demands as;

"The strength of a company such as ours lies not only in the resource fullness of the management but also on the trade and product knowledge of the staff. Experience of international trade and good personal contacts are vital in building up our reputation.
Enthusiasm and stimulation to do a good job are essential for attaining the desired results, Although people do not appear in the balance sheet they still form our most important asset. The individual members of the staff are the ones who have improved our quality and productivity" (Bengt Strömland, 1985).

The staff was set under pressure and the rhetoric also told that; "it is the will to succeed that counts" and "confidence in business is based on the opportunities there are ..." (Bengt Strömland, 1985). But there were no opportunities. 1980 there were 324 employees, in 1981 there were 295 and in 1985 only 105 employees. Even though the employees were down to one third in five years the new house was built and the situation was now dramatic. That reconstruction of knowledge was done methodically in five different steps following a hermeneutical viewpoint, which we called knowledge-gardening, a way to collect and sort out tacit and explicit internal as well as external knowledge. The work plan was to build value creating survival strategies:

Step 1. A review of each division prerequisites.

Step 2. Business, conference in four days.

Step 3. Marketing Plan with communicative and creative strategy.

Step 4. Information for all employees in a day.

Step 5. Implementation and continuous monitoring.

\section{Step 1. A review of each division prerequisites.}

Before the first meeting all necessary background information regarding CA Clase was sent over. This was how the creation of knowledge started. The information was among many other things about divisions, products, knowhow, marketing-efforts, accounts, employees, organization and investments. The first meeting was held the 22nd of September 1986 and was presented the 18th of September to deal with a common view before the companies 75th Anniversary. That common view was about all about knowledge and holistic communication presented in attached articles in advance. The articles also presented how the communication-process corresponds to the organization structure. Lars Lennartsson (1985) also wrote an agenda which told that:

"The forthcoming 75th Jubilee shall give a common view of CA Clase. It's therefore important to discuss competence, strategy, system, common values, staff, style, structure and environment. Also think about activities together with our principles"

That first meeting with a full agenda took two full days together with the divisional managers and was followed by a meeting were all knowledge was identified. This meeting had both formal and informal elements and all was written down on flipcharts for all to complete. After the meeting everyone had one more week to rethink and add comments. Then followed in-depth interviewing with representatives in 
every division. This gave a clear description for every division then aggregated to the company level. This work should be presented week 45/86 and there should also be presented marketing plan, a creative strategy, sketches to be discussed, budgets and work- and time schedule, to be discussed during the planned Business Development Conference. What was not discussed was the defensive organizational issue. That work should come to mean great changes and completely new divisions.

The 29th of September 1986 Bengt Strömland as president sent an invitation to all his staff to attend the conference where issues about the future should be discussed in workshops during two days. The invitation was held short and was followed by a time- and working schedule designed together with the division managers.

\section{Step 2 Business Development Conference in two days}

The declaration of Business Development Conference the 21-22 November 1986 was that CA Clase had diverse activities and difficulties to communicate. From an overall approach (Svanström, 1982) there were a lot of reasons why this should be given the highest priority. Focus was not only on communication but also on contextual and organizational questions.

When opening up the two days of workshops Bengt Strömland told what have been visible so far and why the two days was so important. "Today we can summarize our present situationin terms of a higher degree of market orientation, broaden the knowhow, create one and better profile, create value through knowledge in new segments, establish a market division for coordinating activities, better internal communication and a common attitude and knowledge, better sale and at last better instruments to understand the market needs. That's why it is necessary for the company to work offensive with our knowledge and communication and more companies will see us as an alternative".

The work during the two days was both individual, by division and in new composite groups. A further scanning of knowledge. The first common practice was to create a clear understanding of the situation today and tomorrow for CA Clase. The practice was made to fit newly created and imaginary divisions. That meant to test tacit and explicit knowledge to different constructed situations.

A What do we have B How big is the total market C What could we have

1 Individually

2 By division

3 Coop divisions

4 CA Clase as total

The knowledge creation also included how everybody looked upon their situation and common future. What could they do together in the old and in the new divisions. This analysis made it possible to confront today's business divisions with the newly designed business divisions. That involved not only the communication process but also the organizational structure. Up to now the work had been difficult regarding knowledge because unique especially tacit knowledge was the link for future stay in the company. Because of that the two days' workshop was both formal and informal as well as individual and in several different group constellations.

\section{Step 3. Marketing plans with communicative and creative strategy}

After the Business Development Conference, the transfer of knowledge was carried out in relation to that which had developed during the conference. It was not at all obvious how to shape the different divisions. Thus it was not obvious how to structure the organization either, and whether all employed could stay on. The conference can be said to have created two main tracks, one offensive, communicative, and one defensive, organizational. The work had come to a fork in the road, and the process was becoming painful, but company communication was essential, in order to maintain our image to our customers and other stakeholders. During the weeks 48 - 50, detailed planning of the jubilee year took place, in addition to working out internal communication for distribution before Christmas vacations.

At the board meeting on 12 December 1986, the budget for 1987 was adopted. It contained several changes relating to business direction and organization. The estimated operating result of 1987 was similar to that of 1985 .

"Considering the events of 1986, it is important that the budget be upheld, so as to avoid loss of moment. Our intentional diversion to other areas, as the shipbuilding industry is more or less being wiped out, results in growth of resources in other areas. Initiatives in the Energy and Environment Division will be held back, however, since the efforts made so far have not given or are not expected to give the results anticipated by the people responsible. Therefore, we have pooled the technical resources of the Instrumentation sector and the highly qualified technical staff of the Control Engineering sector. It is important that the company moves in a single direction in order to reach the set goals, so that our 75 year anniversary can be celebrated with confidence." (Strömland, 1986)

In week 50, employees and customers were informed of the situation. Before sending out more detailed information, on 30 December 1986, the traditional Christmas celebration took place, to which the staff were invited together with their wives/husbands. At this time, many had already been given notice, but the emotional speech held by the MD was nevertheless highly appreciated. As usual, he thanked everyone for their fine work during the past year. On 30 December, the MD informed about the necessary structural changes to the company's energy and environmental 
business, to compensate for the fall in oil prices and the lack of a consistent energy policy in Sweden. The MD stressed that resources had to be provided in those areas where they could be best put to use, and that it was important for the company management and the union representatives to stay in agreement about the direction of business, in order to ensure optimal development of the company. It is also important, if employees have other opinions about where resources should be put to use, that their views are presented and discussed. If not, the company's development will slow down and its competitive ability will diminish.

\section{Step 4. Information to all employees during one day}

On 26 January 1987, the communication plan was presented and discussed in the Hörsalen auditorium. This was the Plan for the utilization of knowledge. The plan, or more correctly, the offensive strategy, was developed for the Jubilee Year of 1987. The basis for the necessary changes is a strategic holistic approach, in essence looking into the future. Three main aspects were adopted:

\section{Establishing goals for CA Clase qualitative quantitative}

2. Establishing the essential criteria for futuristic analysis

The customers' needs

The competitors' development

The government's regulatory actions

\section{Reviewing the company's organisation}

Administrative or creative management

Distributing responsibilities and authorities to those having an overview of and being in contact with our customers.

It was established that we have to initiate a progressive process, to prevent the existing organization from setting goals serving its own interests rather than viewing the company from a futuristic perspective.

On 2 February 1987, it was decided that the company, which up till then had been marketed as "a trading house with engineering, your partner" and "a company with an international tradition", from then on was to be marketed as "CA Clase - technology for functionality and utility". To accomplish this and reach the sales goals for 1987, it was decided, on 3 February, that CA Clase was to try out a marketing function, in order to improve coordination of the business activities and to strengthen the profile of CA Clase, and to support marketing and internal information.

This marketing function was to have an external and an internal part. An external resource individual was to continue developing the marketing activities, to help the sales staff in the field and improve the sales figures in relation to budget. One of the primary tasks is to provide the sales staff with better tools, allowing them to devote more time to pure sales work. The internal resource individual was to coordinate the marketing function internally. It may seem obvious to let the marketing function initiate most of the marketing activities, but it is important that his function has information about what is happening in the different departments. That way, the function can contribute actively to sales promoting activities, either for an individual department or for several departments jointly.

The external part of the marketing function would also continue the development of the strategic marketing approach, and be responsible for implementing marketing initiatives within the entire organization, as well as improving efficiency. In addition, the marketing department is to be: "an advisor, a sounding board, an information base creator, a coordinator, a collector of internal information, a press release producer, and in conjunction with the person responsible for sales the implementer of approved measures", (Strömland, 1987). This function was also supposed to develop and stimulate staff welfare, in conjunction with the MD, by means of: "The Clase Magazine, a continuous flow of information, competitions, theme nights and the Clase Club" (Strömland, 1987).

The work had been extremely strenuous during the past year, and there had been many creative late night discussions with the MD. The input to these discussions had been insights in context, organization and innovative capabilities, in relation to possible future scenarios. A lot of ground had been covered, and in the middle of February, the MD presented a book chapter, rewritten by himself. He gave the chapter the heading of "The MD, a driving force behind a winning company".

"Maybe the characteristic of a winning company's MD basically is confidence - an attitude often displayed in team work but sometimes in other, less obvious ways, a feeling of cooperation and mutual understanding, formally or more subtly, encompassing one or two confidants or a complete managing team."

Bengt Strömland remarked that such MD personalities take calculated risks, and he gave much thought to how risks should be taken. He also reflected on ways to calculate the odds, and stressed the need to have some luck. He was worried about the demands made by CA Clase that the MD should have a new role.

"The basic reason for changing the role of the $M D$ is the need to handle the dramatic increase in complexity facing every modern company of medium size. This complexity is reflected in product diversity, volume, technology and system relations, number of types and localization of distribution channels and users, plus the increased pressure from the external environment, the government, the competition, the world economy and society in general. The character of the complexity facing the company, and its growth, decide what type of competence is needed to manage the company, and this in turn helps define the roles the 
MD can and should play. A company consisting of separate business units, such as Kollmorgen, requires division managers able to think strategically and act independently in their own sectors, while keeping the company's interests in focus. The MD of such a company cannot direct and interfere with the daily business activities, if he wants to succeed. Doing so would demoralize the best division managers and make them leave the company."

In all "types of organizations and cultural climates, the MD must be wise enough to either create structures and systems supporting the management needs, or engage others better suited to do this, and delegate appropriate authority to these persons. The MDs of the winning companies appear to have had a feeling for these different factors behind success, mainly because they have been so deeply involved in the business that they have gained a profound insight into the mechanism making it tick, and the ways in which that mechanism changes." He saw different stages of leadership, and pointed out that the most difficult steps of the process of changing the role of the MD probably were (1) the demand to create new teams; and (2) the demand to improve communications. He also indicated various ways to accomplish this personality change on the road to becoming a new type of MD. He envisioned four different ways: (1) structural change; (2) new staff; (3) education; and (4) replanning.

\section{Step 5. Implementation and continuous monitoring}

An issue growing in importance was becoming clear: How to make sure the company succeeded in transforming into the new CA Clase, based on a different set of competencies.

On 26 February 1987, the annual financial statement of the previous year was presented. It was a clear disappointment in relation to the budget. This had been visible already from the third quarterly statement. Three main reasons behind the poor result were suggested: new initiatives in energy saving; new initiatives in control instrumentation; and property rentals. The investment in real estate had been considerable, and the real estate had become too large, since the investment decisions had been made at a time when the customer structure had been more extensive. Now the market was receding and the cost of owning real estate was growing, at the same time.

"Our result was 6 MSEK below budget, and the net profit was zero. Considering the results of previous years and the budgets for 1987 presented by those responsible for each business division, we may regard 1986 as a transition year. The company budget for 1987 indicates a profit of 5 MSEK, with acceptable profitability in all areas. Now we have to implement these plans and work together for the goals of the company" Strömland (1987).
Further, the MD stated that he concurred with the 1978 remark by Eric Österman, namely that;

'"products and services are not sold, they are bought"', and that as a consequence, CA Clase must market their products and services better, and make them known to other customer categories than the shipyards. "It means we must base our efforts on a holistic view of marketing, and work together to give our company a strong profile in the marketplace. This holistic view is illustrated by our common motto: CA Clase, technology for functionality and utility. In other words we shall supply our customers with products and knowledge, and generate added value in the form of maximum functionality and customer benefits. In short: fulfil a need and generate value. This value generation will lead to revenues. Our company culture must be inspired by: having satisfied customers, all employees being aware of their rights and responsibilities, and all of us working on the basis of these common values" (Strömland, 1987).

During the period before Christmas, we produced, transferred knowledge, advertisements, sales materials, and a magazine for distribution both internally and to all customers. All meetings had indicated that most of the divisions were selling products and knowledge to customers who knew absolutely nothing about the other divisions of CA Clase. By displaying the width of our business activities in a customer magazine, the so called "transverse sales" would create new customers for all divisions among the existing customers of other divisions. This proved true, and the effect of that first magazine issue was positive for the entire organization. A common view of the company developed, and this became an instrument in the CA Clase sense-making process. The magazine was also useful as a company presentation, stressing the many aspects of the company business. It conveyed a sense of news value in a way that no brochure or advertisement would have been able to match. It also contained references to and news from the various divisions, and presented new results, popular science articles, pure technology, prospects and retrospects, and product news. It was a flexible and useful way to present the company in its gradually changing form. Economically, it could provide savings, by replacing several other activities.

The changes of divisions already partly in place, which by some people were seen as changes for the worst, could be communicated in a positive and proactive way. The magazine proved long-lived and several issues were published every year. Internally, an assistant editor was appointed for the future.

On 25 January 1987, after lunch (at 13:53), MD Bengt Strömland sent a fax containing both thoughts about the future and views on the major building stones of the company. In his opinion, the most important aspect was to create due respect for the company basics. It was to do with 
having a keen perception, and generating value by using knowledge and providing leadership, and "to make sense", as well as staying ahead in management activities.

This is how Bengt started his fax:

"All of us building this company are unique, in what we stand for, what we do, and how we do it. This demands and deserves contributions and commitments above the ordinary from us all. All must pull their weight with a passionate and contagious enthusiasm, even under pressure. It is also important that we involve each other and delegate tasks to one another. The entire company must be aware of and accept this way of doing work. All must set and seek the objectives of the company, to avoid losing business opportunities. As a consequence, we will make the necessary profit guaranteeing our survival." (Strömland, 1987).

... and he went on to say:

"... words to our managers - some concluding words about our managers, their roles, and about our company. Our managers and leaders draw up goals, they plan and inform, and they divide tasks among the staff, so that each individual knows what must be done and how he or she is contributing to the overall success. The leader also has a strong sense of responsibility for the personal development of each staff member, promoting competence and self-reliant problem solving. It is important to always encourage frankness, to listen with attention, to promote commitment, and to support the members of staff. As a manager, you will not be able to gain personally by this - such is the loneliness of being in command - but that is also the thrill of the business world!"

... and he finished his fax thus:

"words to us all. We must be flexible to the demands of the market. In my view, there are basically three main task categories for us all in this company: (1) Tasks creating satisfied customers. (2) Tasks enabling us to manage and develop the company better. (3) Tasks increasing our net profit. If we can focus on that, our company will be efficient and the administrative load will be minimal. I believe in simplicity: "Simple is beautiful". In addition, our company will be able to offer its employees security and economic gain, making key staff members eager to stay on, and being attractive to new recruits with high qualifications and valuable skills. And we will be able to develop our company and ourselves to be prepared for the future. All that I have said today can be summed up in the phrase":

\section{CA Clase, technology for functionality and utility.}

Let this be our lodestar. Let us commit ourselves to the future and jointly give our company the successes hard work and good ideas entitle it to."

\subsection{Short about CA Clase Today}

The company is still at the same address in their house in Gothenburg and still working with Marin Technology. At the website you can read; "Our ambition is to help the client to a cost efficient overall approach within our core areas including marine navigation- and communication electronic as well as hydro acoustic".

The daughter company CA Clase Ltd is also back in London and can celebrate their 100 year Jubilee next year in London. At the website you can read that it; "is a company specialized in supplying \& supporting high quality products into professional markets. We pride ourselves on our product and application knowledge, pre \& post-sales support which has resulted in a strong and loyal client-base that is constantly expanding. We have two core areas of activity: (1) In-motion-solutions, communication, navigation and entertainment products including satellite TV, satellite internet, satellite communications, satellite navigation (GPS) and integrated entertainment systems for marine, land-mobile and static applications. (2) System-solutions, attitude, heading and position sensors as complete systems or components for OEM and research applications. Core product areas include fluxgate compass, fibre optic gyro, GPS, DGPS, GSM/GPRS, data logging and telemetry".

\section{Case Analysis and Findings}

\subsection{The Overall Pattern and Sense-making Levels}

In the upcoming situation CA Clase had to build a new overall strategy to survive. Their six different areas had conserved unique tacit knowledge. Even the target groups that often were the same didn't know about the different areas so their business could be with a competitor and of that reason they also lost commissions. During the years knowledge had developed within the different areas. Knowledge as a total had been more tacit, changed, were embedded in the organization or at customer as experiences not written down.

In the CA Clase case it is not resources or end products that are in focus, instead it is the processes whereby these resources become constructed. Ahokangas (1998) had a focus on internationalization as resources and process and Nonakas (1994) view of knowledge is taking a processual view. This paper connects two issues by exploration of knowledge creation and usage in the context to the internationalizing process to investigate the hermeneutic making of sense and strategy-building process. Where sense-making shall be looked upon as the ability or attempt to make sense of a situation in order to build strategies and 
survive. So sense-making was the process of creating situational awareness and understanding of the CA Clase situation to make it possible to build these strategies and communicate. Fundamental factors regarding resources were knowledge, sense-making, communication and organizational learning. Huber (1991) conceded that "organizations can learn through conducting a focused search for new information, triggered by a problem or an opportunity, rather than through experience from own activities". In the CA Clase case the sense-making process contained two main logical moments: the retrospective process of interpretation (sense) and the prospective one of enacting a new configuration of environment (making).

The difficult situation made it necessary to work with an overall approach. The focus was value-creation because then money will come. Else you could focus on the money and look upon value creation as an effect. For an industrial company, it's crucial to express functions and necessities to build value for the customer and customers, customer etc. in a chain. The overall components were actors' knowledge, actions taken and expressions made. Expressions meant operative, tactical and strategic and these expressions could be constructed out of the different sense-making steps. The ultimate overall expression was the brand and the pay off. Where the payoff was CA Clase's condensed created value.

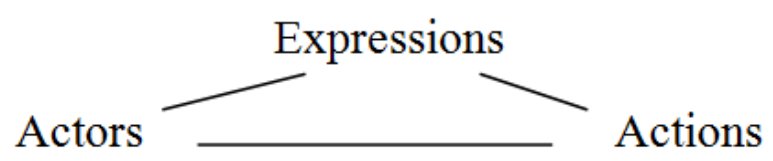

The processual work plan and self-reflecting leadership made up by Bengt Strömland allowed necessary reflections between tacit and explicit knowledge as well as between individual and organizational knowledge. In a sophisticated agenda setting actors were changed and the creative hermeneutic knowledge process could develop and grow. Referring to the processual perspective of knowledge, narratives are seen as a way of making sense. As Weick (1995) put it; "narration is a way of making sense of what is going on or of what has taken place already". The reflected leadership in the process and his narrative approach gave a closer understanding of how the process developed, how barriers were handled and how the sense making internationalizing process emerges. According to Weick (1979) and Deetz (1982) organizations are in a constant process of organizing. This is a way to obtain continuity and coordination which needs actors and roles to coordinate the actions. It is also a way to say that also an internationalization process never ends.

The different stages seen over time in the CA Clase knowledge creating process shows how tacit knowledge transforms into explicit knowledge. This could appear because of the horizontal and vertical overall communication generating actor knowledge and actions. The conference agenda consisting of both formal and informal meetings, with different actors involved at every time, makes the tacit knowledge be written down and converted into explicit. For CA Clase the created new explicit knowledge that overshadowed the tacit knowledge could be utilized in new innovate strategies and expressed. The knowledge spiral was a link between "an individual's tacit knowledge and organizational knowledge through the four modes of knowledge conversion" $(43,34)$.

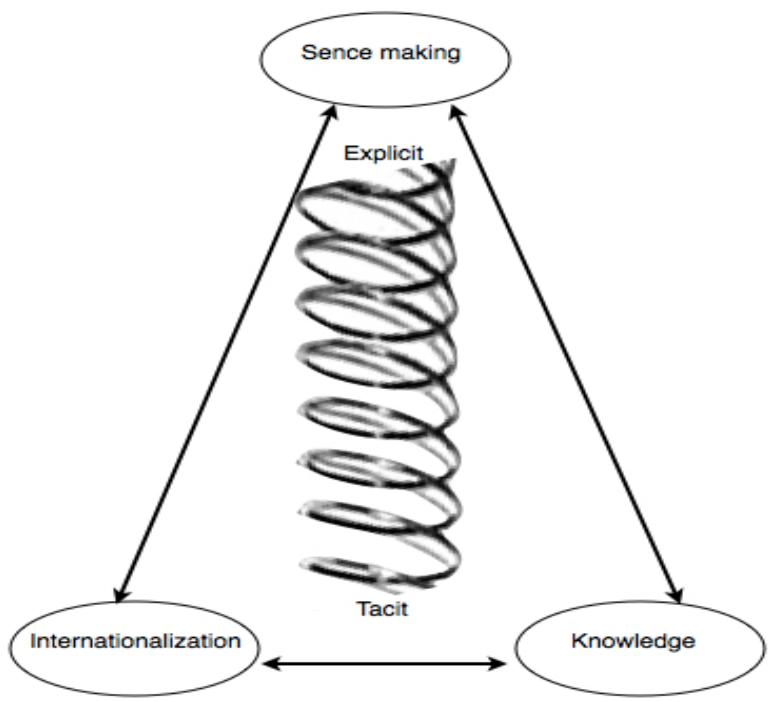

The agendas and narrative leadership eliminated the risk that employees should not tell everything as a way to make themself necessary for the organization disappeared even though the risk for assymetric information regarding tacit but also explicit knowledge of different kinds was obvious. Because of that self-reflecting leadership in the creation of CA Clases knowledge, the agendas was working hermeneutical from operational up to strategic level and build a solid knowledge base for the company to make sense. Obvious is that this reborn process created sense and made CA Clase an internationalization survivor in a changing context. Referring to the dynamic model of Nonaka (1994) and his four modes of creating knowledge through conversion, socialization, combination, and internalization it's obvious that those modes have been reflected. As Nonaka and Takeuchi (1998) argue "certain conditions need to be satisfied for organizational knowledge to take place". In the CA Clase case the organizational intention was to create and utilize knowledge to survive. There was genuine tacit knowledge inside the company that had to be visible and understood to make strategies. This knowledge had been accumulated through many years and through meetings, interviews and reading of protocols and written notes could this knowledge be reconstructed. The approach took a hermeneutical viewpoint and could be compared to a resource-based view here called "knowledge-gardening", which was a way to collect and sort out tacit and explicit internal as well as external knowledge. The schedule was written down in a work plan in five formal steps completed in lots of informal meetings to supplement knowledge. The work was done from the bottom to the top where step 1 was, "a review of each 
division prerequisites". These were mostly interviews and were a first scanning of knowledge to make it possible to continue step 2 which was combinations of groups and individuals put together in a, "business, conference in four days". If step one was the operative ground this was meant to be the tactical ground. For example what could be done and what could not be done. A creative and constructive work with a focus on what the company have of knowledge resources that could create value, who in the market that could be the new target group, what had to be added, what could be left out. These two steps could be compared to Nonakas conversion and socialization steps. The third step was the making of a "marketing plan with communicative and creative strategy" which was the strategic level including new combinations compared to Nonakas (1994) dynamic model. Step 4 was then the "information for all employees in a day" and at last step 5 the "implementation and continuous monitoring". These steps could also be referred to Nonaka (1994) as internationalization and in the CA Clase case to overall expressions in terms of brand and pay-off to survive in the internationalization process. The work plan was meant as a sense-making process to create knowledge from an operative bottom to a strategic top and also to express this knowledge to all actors while actions were taken. In this hermeneutical process, actions were taken, actors leaving and changed when new knowledge resources was created and expressed.

\subsection{Benefits from Sense-making}

CA Clase, a reborn company, is an example of industrial renewal where survival is an obvious effect of the knowledge creation, transfer and utilization in the internationalization process. A key notion in Weicks model is the information environment, which is the external environment where the organization is in. Weick does not describe the external environment as consisting of organizations but of information as the individuals in the organizations reacts upon, i.e. the information that have relevans for the organization in some way. This information makes sense and the concept of sense-making contains two main logical moments: the retrospective process of interpretation (sense) and prospective one of enacting a new configuration of environment (making). The sense-making process influences what and how data is to be considered and judged by the subject in order to implement future actions. This is what the CA Clase case shows. In order to implement future actions (55) knowledge was expressed and communicated in every step and finally as a strategic tool based on the overall approach. The process in CA Clase made sense because the work plan had a strong reflexive quality to the process (58).

In the CA Clase case the company created knowledge and utilized technical value through products and knowledge in an ever-changing international context. The survival culture inside the company saw the need to look upon internationalization as an ongoing process and not only as a crossing-the-border concept and upon knowledge as "fresh weight" factors that still make sense. This was done through the approach from bottom to top analysis of knowledge during the knowledge screening process. The work plan made use of the hermeneutical spiral which was divided into three company knowledge levels that made the basis for the strategic levels. This made it possible to be both defensive and offensive. Defensive: because of all changes caused by the knowledge work. As many as $60 \%$ of all employees had to leave when departments within the organization was changed. Offensive with communication which made it possible to get business running despite all the changes. The communication also had a positive effect on the employees left in the organization and of course on the clients.

These levels are first the operational. This is a situation where the company changes and has extreme problems to survive. The next level is tactic. The knowledge is still scarce and the company could have lost the direction through weak leadership and bad overall approach. On this product level the creativity to come up with new ideas is not enough. The company needs innovation, the taking of new and existing ideas and turning them into action (28). For this, there needs to be knowledge not only creativity. The management or strategic level should be the ultimate overall knowledge base. In the CA Clase case all efforts was focused on how to gather, sort out and build up that necessary knowledge from tacit to explicit, but also from tacit to tacit and explicit to explicit and so on in all kinds of formal and informal meetings. By writing down tacit knowledge it turned into something explicit and "true" and then easier expressed and discussed with colleagues with further tacit or explicit knowledge. That made the knowledge grow and not been forgotten, this had to be an ongoing never-ending process and not only a crossing-the-border process.

There were lots of barriers also in the CA Clase case. Not only fear because people could loose their employment if tehy gave away too much tacit or explicit knowledge. All those meetings and communication arenas were also a kind of an organizational learning process were everybody became involved and talked to. To be offensive was also the reason why the first number of the paper was sent to all customers around the company which made contacts so new relations opened up. That made an impression inside CA Clase so the embedded fear that was a defensive factor became shadowed. It became obvious for all interests around the company that creation and utilization of knowledge in the internationalization process made sense.

\subsection{Creation and Utilization of Knowledge}

When working with CA Clase their international experience was necessary and useful as the company operated in that perspective. All of the employees had also worked with advanced international products and services for many years and had developed deep knowledge, both 
tacit and explicit about their applications. They participated continuously in education offered by the supplier and the CA Clase divisions have more or less been independent parts of the whole CA Clase company because they were responsible for different applications. During many years the market demand had been high and that preserved the company in company feeling. The socialization part of Nonakas (1994) modes was therefore of great importance as a way to obtain more common knowledge in a first step. When this knowledge became visible there appeared an offensive feeling which was further strengthened when a company paper was sent to all CA Clase customers. They get the impression that; why not buy even this and that from the same company. In short term that meant more sale and a more secure staff, which made it much easier with less barriers in the externalization part of the process referring to Nonakas (1994) mode. This was well planned and as mentioned before consisted of both formal and informal meetings as well as different combinations of employees so that the communication became both horizontal and vertical. The tacit knowledge became explicit when written down and further on published in a new customer paper. CA Clase was looked upon as offensive even though the situation was defensive. Looking upon the knowledge creation in terms of a hermeneutic spiral I divided that into three different levels, from the botton the operative, then tactic and last the strategic or management level. When creating knowledge it was done in a first step as an overall view where socialization and externalization modes (42) were the most significant. During the work process the combination mode (42) was added because the combination of knowledge in terms of products and services to other customers demanded new divisions. CA Clase kept the initiative because of good self-reflective leadership and communication and when creating new divisions with new combinations also new knowledge was necessary. This knowledge should be used in other applications as explicit and tacit and therefore new tacit knowledge was necessary. Nonaka (1994) looks upon this as an interaction between the organization and the individual. In the CA Clase case something new as a total was created and formed the value created strategic knowledge necessary for the internationalization process. They had planned and reached the hermeneutic strategic level which made it possible to form the brand and build the payoff, which is the condensed value in a small sentence. But a lesson was learned that knowledge must be looked upon as fresh weight and worked with as a never-ending interplay between the actors. The leadership of the manager and his communicative skill made a safe guidance in the process and in narrative terms he could set the condensed vision in terms of the payoff "technique for function and value creation" which became the signum to create clients customer value and to make further sense.

\section{Conclusions}

The processual work plan and self-reflecting leadership set up by Bengt Strömland allowed necessary reflections between implicit and explicit knowledge as well as between individual and organizational knowledge. In a sophisticated agenda setting the actors were changed and the creative hermeneutic knowledge process could be developed and grow. Referring to the processual perspective of knowledge, narratives are seen as a way of making sense. As Weick (1995) put it;" narration is a way of making sense of what is going on or of what has taken place already". The reflected leadership in the process and the narrative approach of Bengt Strömland gave a better understanding of how the process developed, how barriers were handled and how the sense making internationalizing strategy process emerges. According to Weick (1979) and Deetz (1982) organizations are in a constant process of organizing. This is a way to obtain continuity and coordination which needs actors to coordinate the actions. It is also a way to say that an internationalization process never ends as long as there are linkages between in a company structure.

The different stages seen over time in the CA Clase knowledge creating process shows how implicit knowledge transforms into explicit knowledge. This could appear because of the horizontal and vertical overall communication, generating actor knowledge and then actions and expressions. The conference agenda consisted of both formal and informal meetings, with different actors involved at every time, makes the implicit knowledge be written down and converted into explicit. For CA Clase the created new explicit knowledge that overshadowed the implicit utilized knowledge could be transferred into new innovative strategies and communicated by expressions. The interaction between the "individual's implicit knowledge and the aggregated organizational knowledge" became hermeneutical knowledge in a spiral.

All agendas and the narrative leadership formed by VD Bengt Strömland eliminated the risk that employees should not tell everything as a way to make them self-necessary. For the organization the risk for assymetric information regarding implicit but also explicit knowledge was obvious. Because of that a self-reflecting leadership when creating the CA Clases need for knowledge was necessary. The different agendas that was made for the process of knowledge creation, transfer and utility was working hermeneutical from operational up to strategic level and it helped to build a solid knowledge base for the company. Obvious is that this reborn process created sense and made CA Clase an inter-nationalization survivor in a changing context. In the CA Clase case the main organizational intention was to create and utilize knowledge to survive. There was genuine implicit knowledge inside the company that had to be visible and understood to build common strategies. This knowledge had been accumulated and embedded during many years. Through meetings, interviews, reading of protocols and written notes this 
knowledge could be reconstructed. The work-perspective was hermeneutical and could at the same time be looked upon as a resource based view. That work was here called knowledge gardening, which was a way to collect and sort out implicit and explicit internal as well as external knowledge. The schedule was written down in a work plan in five formal but creative steps completed in lots of informal meetings to supplement knowledge creation. The work was done from the bottom to the top where step 1 was, "a review of each division prerequisites". This were mostly interviews and was a first scanning of knowledge to make it possible to continue step 2 which was combinations of groups and individuals put together in a, "business, conference in four days". That was also a transfer of knowledge trying to find the way. If step one was the operative ground this was meant to be the tactical ground. For example what could be done and what could not be done. A creative and constructive work with a focus on what the company have of knowledge resources that could create value, who in the market that could be the new target group, what had to be added, what could be left out. The third step was the making of a "marketing plan with communicative and creative strategy" which was the strategic level including new combinations. Step 4 was then the "information for all employees in a day" and at last step 5 the "implementation and continuous monitoring". These steps could also be referred to as internationalization and in the CA Clase case to overall expressions in terms of brand and pay-off to survive in the internationalization process. The work plan was meant as a sense making process to create knowledge from an operative bottom to a strategic top and also to express this knowledge to all actors while actions were taken. In this hermeneutical process actions was taken, actors leaving and changed when new knowledge resources was value created and expressed. The level of actor initiative was carried out to be high, that was inbuilt in the different steps.

CA Clase became a reborn company and an example of industrial renewal, where survival is an obvious effect of the knowledge creation, transfer and utilization in the internationalized context. A key notion in Weicks model is the information environment, which is the external environment the organization is in. Weick does not describe the external environment as consisting of organizations but of information as the individuals in the organizations reacts upon, i.e. the information that have relevans for the organization in some way. This information makes sense and the concept of sense making contains two main logical moments: the retrospective process of interpretation (sense) and prospective one of enacting a new configuration of environment (making). The sense making process influences what and how data is to be considered and judged by the subject in order to implement future actions. This is what the CA Clase case shows. In order to implement and make future actions (55) knowledge was expressed in every step and finally as a strategic tool based on an overall approach. The process in CA Clase made sense because the work plan had a strong reflexive quality to the process (58).

In the CA Clase case we can see how the company created knowledge and utilized technical value through products and knowledge in an ever-changing international context. The survival culture inside the company saw the need to look upon internationalization as an ongoing process and not only as a crossing-the-border concept and upon "knowledge as fresh weight" factors that still make sense. This was done through the approach from bottom to top analysis of knowledge during the knowledge-gardening process. The knowledge-gardening made use of the hermeneutical spiral which was divided into three company knowledge levels that made the basis for the strategic levels. This made it possible to be both defensive and offensive in actions, defensive because of all changes caused by the knowledge work and as many as $60 \%$ of all employees had to leave when divisions within the organization was changed. Offensive expressive actions made it possible to get business running despite all changes. The expressions here called, management by expressions, also had a positive and trusting effect on the employees that were still employed in the organization and of course on the clients.

Knowledge creation worked from the bottom and the first strategy level for CA Clase was the operative, a situation where changes meant extreme problems to survive with nothing to express. The next level was tactic or administrative. The knowledge was still scarce and CA Clase could have lost the direction through weak leadership and bad overall approach. On this so called product level, the creativity to come up with new ideas is not enough. The company needs innovation and to take this new and existing ideas and turn them into action (Gurteen, 1998). For this there need to be knowledge about how to innovate not only creativity. The management or strategic level should be the ultimate overall knowledge base. In the CA Clase company all efforts was focused on how to gather, sort out and build up that necessary knowledge from implicit to explicit, but also from explicit to explicit and so on in all kinds of formal and informal meetings. By writing down implicit knowledge it turned into something explicit and trustworthy also easier expressed and discussed with colleagues with further implicit or explicit knowledge. That made the knowledge grow and not been forgotten. It had to be an ongoing never ending internalization process not only a crossing-the-border process.

There were lots of different barriers in the CA Clase case. It is often because of fear as asymmetric information, silence, informal contacts, disinformation etc., but also with a lack of market knowledge and unknown risks. Many employees felt they could loose their employment if they told to much both in terms of tacit, implicit or explicit knowledge. All those meetings and communication arenas were as a whole an offensive organizational learning process were everyone was forced to be involved, listen to and talked with.

To be offensive of time reason, a first expression as a 
company a publication of the company magazine was published and sent out to all employees, customers and interest groups around the company. That magazine created contacts so new relations opened up. That expression in the form as a publication made an impression inside CA Clase so that the embedded fear that was a defensive factor became shadowed down. It became obvious for all interest groups around the company that creation, transfer and utilization of knowledge in the internationalization process made sense and was a way of building strategies for expressions as communication.

When working with CA Clase the international perspective was necessary as the company operated in that context. All of the employees had also worked with technically advanced and international products and services for many years and had developed deep as well as comprehensive knowledge; tacit, implicit as well as explicit about the applications. They participated continuously in education offered by the supplier and the CA Clase divisions have more or less been independent parts of the whole CA Clase company because they were responsible for different applications. During many years the market demand had been high and that had preserved the company in a laid back feeling. When this knowledge became visible there appeared an offensive feeling which was further strengthened when the magazine was sent out. Customers to specific divisions get the impression why not buy even this and that from the same company. In short term that meant more sales. And it also meant more secure staff which made it much easier with the problem of barriers. This was well planned and as mentioned before consisted of both formal and informal meetings as well as different combinations of employees so that the communication became both horizontal and vertical. The implicit knowledge became explicit when written down and further on published in the new customer paper. CA Clase was looked upon as offensive even though the situation was defensive. Looking upon the knowledge creation in terms of a hermeneutic spiral the knowledge created was divided into three different levels, from bottom the operative, then tactic and last the strategic or institutional level. CA Clase kept the initiative because of good self-reflective leadership and narrative communication when creating new divisions with new combinations and applications. Then also new knowledge was necessary. In the CA Clase case something new as a total was created and formed the value created strategic knowledge necessary for the internationalization process. They had planned and reached the hermeneutic strategic level which made it possible to form the brand and build a payoff, which mentioned again were the condensed client value in a small sentence. But now a lesson had been learned that knowledge must be looked upon as fresh weight and worked with as a never-ending interplay between the actors inside the international company structure. The leadership of the manager and his communicative skill made a safe guidance in the process and in narrative terms he could set the condensed vision in terms of the payoff; "technique for function and value creation". To create customers, customer value that could make further sense, that became the signum for CA Clase

\section{Future Research}

The purpose of this study was to generate a better understanding to how creation, transfer and utilization of knowledge is necessary to make sense and overwin barriers to survive, to be still running and sustainable in the international context. This study gives a thumbnail image of the addressed research question. The company CA Clase has survived and there is an obvious connection between internationalization and the creation, transfer and utilization of knowledge. It is also obvious that this made sense for developing competitive advantage. The CA Clase case shall also be looked upon as a reborn process or knowledge renovating process.

In order to investigate the need for continuous knowledge development in the internationalization process to make sense and survive I propose further research. This is in progress and a quantitative broad study of 168 companies to analyze and evaluate the indicators and barriers. I study the 168 companies in order to investigate the role of knowledge, communication and barriers for a sustainable internationalization. How have companies managed to survive by working with a knowledge gardening process?

Questions that will be focused are; What happened with the companies in their internationalization process? How did companies manage their knowledge process and communication? What were the institutional and cultural barriers? How could knowledge be managed and communicated for a sustainable internationalization process? How can a company work with an overall approach?

\section{Acknowledgements}

I want to thank Bengt Strömland and Lars Lennartsson with employees at CA Clase.

I also want to thank my creativity that enabled the articles published on this subject in the early 80's. These attracted companies and founded Svanstroem Angus Company. That was my first knowledge creation, transfer and utility with an overall approach.

\section{REFERENCES}

[1] Ahokangas, Petri (1998) Internationalisation and resources : an analysis of processes in Nordic SMEs, University of Vaasa

[2] Blackler, Frank (1995) Knowledge, Knowledge Work and Organizations: An Overview and Interpretation Organization Studies, Vol. 16, No. 6, 1021-1046, The Management School, 
Lancaster University, U.K.

[3] Bridge, Simon, O’Neill, Ken \& Cromie, Stan, 1998, Understanding enterprise, entrepreneurship and small business, MacMillan Business

[4] Bohm, David (1988) On Creativity, London \& New York : Routledge

[5] Brookings, A. (1997) Intellectual Capital: Core assets for the third millenium enterprise, Thomson, London

[6] Calof, J.L., Beamish, P.W. (1995), Adapting to foreign markets: Explaining internationalization, International Business Review, Vol. 4 pp.115 - 131.

[7] Carson, D. and Coviello, N (1996) Qualitative Research Issues at the Marketoing/Entrepreneurship Interface, Marketing 5ntelligence and Planning, 14.6 51-58

[8] Czarniawska, Barbara (1997) Narrating The Organization: Dramas of Institutional Identity. University of Chicago Press, London.

[9] Czarniawska, Barbara (1998) A Narrative Approach to Organization Studies. Sage, Thousand Oaks.

[10] Czarniawska, Barbara (1999) Writing Management. Oxford University Press, Oxford.

[11] Czarniawska, Barbara (2006) The uses of Narrative in Organization Research, paper

[12] Chaston, I. (2000), Entrepreneurial Marketing: Successfully Challenging Market Convention, MacMillan.

[13] Choo, C., Bontis, N. (Eds.), 2002. The Strategic Management of Intellectual Capital and Organizational Knowledge. Oxford, University Press, Oxford.

[14] Cohen, D., Nisbett, R. E., Bowdle, B. F. and Schwartz, N. (1996). Insult, aggression, and the southern culture of honor: An "experimental ethnography." Journal of Personality and Social Psychology, 70, 945-960.

[15] Cohen, W.M. \& Levinthal, D.A, (1990). Absorptive capacity; A new perspective on learning and innovation. Administrative Science Quarterly, 35, 128-152.

[16] Cook, S. D. N. and Brown, J. S. (1999) "Bridging epistemologies: the generative dance between organizational knowledge and organizational knowing", Organization Science, Vol. 10, No. 4, 381-400, July - August

[17] Deetz, S. (1982) "Critical Interpretive Research in Organizational Communication", Western Journal of Speech Communication 46: 131-49.

[18] Drucker, Peter F., (1968) The Age of Discontinuity, Harper \& Row, New York

[19] Drucker, Peter F., (1988) The Coming of the New Organization, Harvard Business Review on Knowledge Management, 66(1)

[20] Eisenberg (1986)

[21] Eisenhardt, K. M. (1989). Building theories from case study research. Academy of Management Review, 14, 532- 550.

[22] Fillis, I. \& McAuley, A. (2000) Modeling and measuring creativity at the interface, Journal of Marketing Theory and
Practice 8 (2), 8-17.

[23] Fillis, Ian (1999) A Cross-Cultural Comparison of the Internationalisation Process of SMEs: An examination of the UK and Irish craft sector. Doctoral dissertation, University of Stirling.

[24] Fillis, Ian (2002) The Internationalization process of the craft microenterprise. Journal of Development Entrepreneurship, Vol. 7, No. 1, pp. 25-43.

[25] Ghymn, Liesch \& Mattsson, (1999)

[26] Gjellerup, P. (2000), "SME support services in the face of globalisation", concerted action seminar, Opening address, Conference Proceedings, Danish Agency for Trade and Industry, Copenhagen, pp. 16-28.

[27] Gruber, H.E., Terrell G., Wertheimer, M. (1962): (eds) Contemporary approaches to creative thinking, The Atherton press Behavioral science series. University of Chicago.

[28] Gurteen, D., (1998), Knowledge, Creativity and Innovation, Journal of Knowledge management, Vol. 2 Number 1 september 1998

[29] Hackley, C.E. and Mumby-Croft, R. (1998) Marketing Entrepreneurs as Creative Agents in a social Matrix : Towards a Theoretical Framework for Marketing Entrepreneurship, in Academy of Marketing UIC/AMA Symposia on Marketing and Entrepreneurship Interface, Proceedings 1996-1998, edited by B. Hubert, J Day, and E Shaw, Northhampton, England, Nene University College, 505-513

[30] Huber, G. P. (1991), "Organizational Learning. The Contributing Processes and the Literatures", Organization Science, 2 (1), 76-92, 88-115.

[31] Johanson, J., Mattsson, L.-G. (1993), "Internationalization in industrial systems - a network approach, strategies in global competition", in Buckley, P.J., Ghauri, P.N. (Eds), The Internationalization of the Firm: A Reader, Academic Press, London, pp.303-22.

[32] Johanson, J. and Vahlne, J.-E. (1990), "The mechanism of internationalization", International Marketing Review, Vol. 7 No. 4, pp. 11-24.

[33] Johanson, J. and Wiederscheim-Paul, F. (1975), "The internationalization of the firm - four Swedish cases", Journal of Management Studies, Vol. 12 No. 3, pp. 305-22.

[34] Karlsen, T., Benito, G.R.G., Silseth, P.R., Welch, L.S. (2003), "Knowledge, internationalization of the firm, and inward-outward connections", Industrial Marketing Management, Vol. 32 pp.385-96.

[35] Korhonen, H. (1999), "Inward-outward internationalization of small and medium enterprises", doctoral dissertation, Helsinki School of Economics and Business Administration, Helsinki.

[36] Klein et al. (2006).

[37] Lave, J. and Wenger, E. (Eds.) (1991) Situated learning Legitimate peripheral participation, Cambridge University Press, Cambridge

[38] Gherardi, S. and D. Nicolini (2000). "To Transfer is to Transform: the Circulation of Safety Knowledge" 
Organization 7: in the press. An empirical and theoretical account of organisational decision making, which uses, in part, actor-network theory. See the commentary by Law (2000).

[39] Lehtinen, U., Penttinen, H. (1999), "Definition of the internationalization of the firm", in Lehtinen, U., Seristoe, H. (Eds),Perspectives on Internationalization, Helsinki School of Economics and Business Administration, Helsinki, pp.3-19.

[40] Luostarinen, R. (1979). Internationalization of the firm. Helsinki: Helsinki School of Economics and Business Administration.

[41] Nevett, T. and Nevett, L. (1987) "The Origins of Marketing: Evidence for Classical and Early Hellenistic Greece", in Nevett, T. and Hollander, S.C. (eds) Marketing in Three Eras, Proceedings of the Third Conference on Historical Research in Marketing, Michigan State University.

[42] Nonaka, I. (1994) A dynamic theory of knowledge creation. Organization Science, 5; 14-37.

[43] Nonaka. I. and Takeuchi, H. (1995) The knowledge Creating Copany, Oxford University Press, New York

[44] Patton, M. Q. (1990). Qualitative Evaluation and Research Methods (2nd ed.). Newbury Park, CA: Sage Publications, Inc.

[45] Pfeffer, J., Sutton, R.I.: "The Knowing-Doing Gap: How Smart Companies Turn Knowledge into Action"; Boston: Harvard Business School Press, 2000.

[46] Edenius, M, Hasselbladh, H. (2002) "The Balanced Scorecard as Intellectual Technology”, Organization 9(2): 249-273.

[47] Olive et al, (2003).

[48] Ramplay, M. (1998)., "Creativity", British Journal of Aesthetics, Vol 38, No 2, pp125-135
[49] Rentschler et al. (1996, 1997, 2000)

[50] Ruzzier, M., Hisrich, R.D. and Antoncic, B. (2006) SME Internationalization Research: Past, Present and Future, Journal of Small Business and Enterprise Development, 13(4), 476-497.

[51] Stewart, T. A. (1997) Intellectual Capital. The new wealth of organizations. Currency Doubleday, New York

[52] Sveiby, K-E. (1997) The new organizational wealth. Managing and measuring knowledge-based assets, Berret-Koehler, San Fransisco.

[53] Smircich, Linda and Stubbart, Charles (1985) Strategic management in an enacted world. Academy of Management Review 10, pp. 724-736

[54] Vygotsky, L. S. (1962). Thought and language. Cambridge, MA: The MIT Press. Published originally in Russian in 1934.

[55] Weick, K. E. (1979a). Cognitive processes in organization. In B.M. Staw (Ed.), Research in organizational behavior. (Vol. 1, pp. 41-74). Greenwich, CT: JAI Press.

[56] Weick, K. E. (1979b). The social psychology of organizing (2nd ed.) Reading, MA: Addison-Wesley.

[57] Weick, K. (1988), Enacted sensemaking in crisis situations. Journal of Management Studies, 25, 305-317.

[58] Weick, K. E. (1995). Sensemaking in Organizations. Thousand Oaks CA: Sage Publications.

[59] Welch, L. S. and R. Luostarinen (1988), 'Internationalization: Evolution of a Concept', Journal of General Management, 14 (2), 34-55

[60] Yin, R. (1994) Case study research: Design and methods (2nd ed.). Beverly Hills, CA: Sage Publishing.

[61] Ylinenpää (1996) 